\title{
Print Cultures in the Making in 19th- and 2oth-Century South Asia: Beyond Disciplinary Boundaries
}

\author{
Cristina Pecchia | ORCID: 0000-0002-9462-4417 \\ Institute for the Cultural and Intellectual History of Asia (IKGA), \\ Austrian Academy of Sciences (oEAW), Vienna, Austria \\ cristina.pecchia@oeaw.ac.at
}

Johanna Buss | ORCID: 0000-0002-9363-8171

Seminar für Südasienkunde und Indologie, Martin-Luther-Universität

Halle-Wittenberg Halle, Germany

johanna.buss@suedasien.uni-halle.de

\author{
Alaka A. Chudal | orcid: 0000-0002-7308-7384 \\ Institut fur Sudasien-, Tibet- und Buddhismuskunde, Universität Wien, \\ Vienna, Austria \\ alaka.chudal@univie.ac.at
}

\begin{abstract}
The study of the history of print technology in South Asia is a multidisciplinary enterprise which involves attentive consideration of the cultural and linguistic diversity of the region, as well as of the historical time in which print technology was massively adopted, namely the colonial period. Here, we focus on the complex fabric of relationships between print and modes of recording and using texts in long present oral and manuscript cultures, also pointing out the limits of applying interpretative models based on the cultural history of Europe to the histories of print in South Asia. Furthermore, we present aspects of the formative stage of print cultures concerning Vedic, Limbu, Nepali, Newari, and Tamil textual traditions - which are studied in the essays of this special issue. This multi-layered perspective helps making sense of social and cultural dynamics concerning the uses of printed books, the (new) meanings associated with them, and the formation of hegemonic configurations within literary and religious traditions.
\end{abstract}




\section{Keywords}

print - manuscripts - orality - South Asia - textual transmission - textual circulation

For a book is never simply a remarkable object. Like every other technology it is invariably the product of human agency in complex and highly volatile contexts which a responsible scholarship must seek to recover if we are to understand better the creation and communication of meaning as the defining characteristic of human societies.

D. F. MCKENZIE, Bibliography and the Sociology of Texts ${ }^{1}$

\section{Introduction}

A massive adoption of print technology took place in South Asia during the nineteenth century. It involved a complex interplay with the manuscript and oral cultures through which individuals and communities for centuries attended to texts, reproduced them, made them public, and enabled their circulation. Therefore, the study of the history of print cultures across nineteenth- and twentieth-century South Asia is a multidisciplinary enterprise, whose intrinsic vastness combines with the cultural and linguistic diversity of the region, and is complicated by the historical conditions of the period, which corresponds to the colonial and postcolonial epoch. In investigating the phase in which specific texts or groups of texts turned to print, the five articles in this issue of Philological Encounters examine cultural, social, religious, and political factors that constitute the fabric of print cultures in South Asia, and devote attention to largely unexplored matters concerning interaction and continuities with the existing oral and manuscript cultures. Such matters were also the focus of the symposium "Manuscript, Print and Publication Cultures in South Asia:

1 Cambridge: Cambridge University Press, 1999, 4. 
From the 19th Century to the Present", held on September 2O-21, 2018 at the University of Vienna, ${ }^{2}$ and from which four of the present articles derive.

In speaking of print culture, we refer to a set of aspects concerning the production, distribution, use, and circulation of texts reproduced by means of print technologies, namely xylography, lithography, movable-type letterpress, or other techniques used to impress a text on a support. The study of print cultures is not limited to the material aspects of documents and books and their production, but ideally draws on social, cultural, and intellectual history, history of literacy and reading, and economic and political history-which, in the case of South Asia, poses a number of specific challenges. In view of the linguistic and cultural diversity of the vast South Asian region, a plurality of print cultures can be identified according to categories such as region, language, or time. Such a plurality emerged in the nineteenth century, when lithography and other print technologies were established in east and north India and print became a widespread technology in South Asia. ${ }^{3}$ Now classical books such as A. K. Priolkar's The Printing Press in India (Bombay 1958), Graham Shaw's Printing in Calcutta to 1800 (London 1981), and B. S. Kesavan's History of Printing and Publishing in India (1985) have provided pioneering overviews of the history of printing in South Asia, which began when Jesuit missionaries first operated a movable type press in Goa in 1556. Literature has rapidly grown over the last two decades or so, and includes the essays collected in the volumes Print Areas. Book History in India (2004), Moveable Type: Book History in India (2008), and Founts of Knowledge (2015), edited by Abhijit Gupta and Swapan Chakravorty, and in the History of the Book in South Asia, edited by Francesca Orsini (2013), as well as in Facing the World: Towards a Global History of Non-Latin Type Design, a special issue of Philological Encounters on nonEuropean type design edited by Thomas S. Mullaney (2018). Other important studies have focused on specific themes and regions, such as print as an instrument for shaping social identities and consolidating power in colonial Bengal (Ghosh 2006), the prominent Naval Kishore Press from Lucknow (Stark 2008), the scholarly and subaltern publishing of Tamil books during the colonial period (Venkatachalapathy 2012), the history of print culture related to Sanskrit texts (Formigatti 2016), or nineteenth-century projects for the print of Vedic texts (Galewicz 2O2O). ${ }^{4}$ The significant progress brought about by these

2 The symposium was organized by the Department of South Asian, Tibetan and Buddhist Studies (ISTB) of the University of Vienna and the Institute for the Cultural and Intellectual History of Asia (IKGA) of the Austrian Academy of Sciences.

3 A map of the rise of the printing press across South Asia until the year 1900 is provided in Ulrike Stark, Chapakhana. https://chapakhana.rcc.uchicago.edu, 2018-2021, accessed April 14, 2021.

4 See "Bibliography" for details. 
studies makes it even more evident that we need to expand our knowledge about places far from important urban centres and time periods other than the late nineteenth and early twentieth centuries (when local entrepreneurship took the lead of print activity in South Asia). Moreover, we need to investigate diachronic and synchronic relationships between print and other modes of record, transmission, and circulation of texts. These investigations help us make sense of social and cultural processes connected to print as they put the printed book into a multi-layered perspective and look at it from a wider and deeper-in-time point of view.

The five contributions in this issue present case studies within print cultures belonging to textual traditions as diverse as the Vedic, Limbu, Nepali, Newari, and Tamil ones. While exploring stages in the history of print in South Asia from the early nineteenth century to the twentieth century (with some glimpses into the twenty-first century), these studies highlight the complex fabric of relationships between print and modes of recording and using texts in long present oral and manuscript cultures. Together, they illuminate important aspects of such relationships (which might not be so apparent from studies that merely focus on the processes of production and circulation of printed texts) as well as dynamics in the uses of printed books, the meanings associated with them, and the formation of hegemonic configurations within literary and religious traditions.

\section{Print at the Interface with Manuscript and Oral Cultures}

In the case of Europe, the interplay between print and manuscript cultures has long since been extensively investigated. The Fifteenth Century Book by Curt Bühler (1960) and numerous publications that followed have surveyed new agencies and agents of change that appeared in modern Europe during the transition from manuscript to print culture in the span of time between the fifteenth and seventeenth century. ${ }^{5}$ These studies have prompted several specialists to question the very model that sees the printed as separated from the handwritten and contrasts it as characterized by fixity. ${ }^{6}$ Such a

5 In critically reviewing the idea of a printing revolution in early modern Europe, David McKitterick has argued that it took almost 400 years for some changes related to the printed reproduction of texts to be assimilated in societies across Europe; see David McKitterick, Print, Manuscript and the Search for Order, 1450-1830 (Cambridge: Cambridge University Press, 2003).

6 As regards printing in Europe, McKitterick has argued that until the early nineteenth century there was a great "range of variables, all denying the possibility of speaking confidently of a sequential history" (McKitterick, Print, Manuscript and the Search for Order, 23o). Peter Stallybrass has provocatively spoken of a manuscript revolution brought about by printing 
model is quite problematic in the case of different Asian regions, too. In China and Japan xylography was adopted as early as the late seventh and eighth century CE, respectively, but only the diffusion of lithography and movabletype letterpress in the late nineteenth century gave rise to a radical change in the use of print technology. ${ }^{7}$ Tibetan cultural history equally displays notable aspects of coexistence and interaction between manuscript and print cultures. ${ }^{8}$ The mechanical reproduction of texts may not be given primacy over the handwritten for centuries within any given society, with different technologies of the written in fact coexisting, albeit undergoing adaptive changes. South Asia surely is no exception to this, but it also represents an anomaly that has not yet been fully explained, namely that an indigenous print industry first developed in nineteenth-century Bengal. The study of print cultures and their interdependence with manuscript cultures presents various challenges in the case of South Asia, not only because of the vastness and cultural complexity of the region, but even more so because of our very lacunary knowledge of the history of its manuscript cultures ${ }^{9}$ — whose spectrum is broad and diverse, and which requires careful consideration of their social and political context as well as of the language(s) used by the agents involved over different and normally quite long spans of time. ${ }^{10}$

mainly because of "its incitement to writing by hand"; see Peter Stallybrass, "Printing and the Manuscript Revolution," in Explorations in Communication and History, ed. Barbie Zelizer (New York: Routledge, 2008), 111.

$7 \quad$ Among publications concerning China, see Printing and Book Culture in Late Imperial China, edited by Cynthia J. Brokaw and Kai-Wing Chow (Berkeley: University of California Press, 2005), and Hang Lin and 林航, "Intersecting Boundaries: Manuscript, Printing, and Book Culture in Late Ming China," Oriens Extremus $5^{2}$ (2013): 263-304. With regard to Japan, see more recently Linda H. Chance and Julie Nelson Davis, "The Handwritten and the Printed. Issues of Format and Medium in Japanese Premodern Books," Journal for Manuscript Studies 1 (2017): 90-114.

8 See, in particular, Kurtis Schaeffer, The Culture of the Book in Tibet (New York Chichester, West Sussex: Columbia University Press, 2009); Orna Almogi, ed., Tibetan Manuscript and Xylograph Traditions. The Written Work and Its Media within the Tibetan Cultural Sphere (Hamburg: Department of Indian and Tibetan Studies, University of Hamburg, 2016); and H. Diemberger et al., eds., Tibetan Printing: Comparisons, Continuities, and Change (Brill: Leiden, 2016).

9 Insightful considerations are offered in Anindita Ghosh, "An Uncertain 'Coming of the Book': Early Print Cultures in Colonial India," in Book History 6 (2003): 23-55; Camillo Formigatti, "Manuscript Studies: Crisis on Infinite Methods," in The Study of Asia between Antiquity and Modernity, eds. Elisa Freschi et al., 43-9. Special issue of Rivista degli Studi Orientali 84 (2011); and Jan E. M. Houben and Saraju Rath, "Introduction: Manuscript Culture and Its Impact in 'India': Contours and Parameters," in Aspects of Manuscript Culture in South India, ed. S. Rath (Leiden: Brill, 2012), 1-53.

10 General overviews are for example offered by Dominik Wujastyk, "Indian Manuscripts," in Manuscript Cultures: Mapping the Field, eds. Jörg Quenzer et al. (Berlin: Walter 
Moreover, the study of print cultures in South Asia ought to consider the presence and impact of oral cultures in the textual and educational histories of the region. For example, oral recitation and memorisation of Sanskrit texts still famously feature as common methods in traditional educational settings ${ }^{11}$ and the prestige of orality, also in contrast to the written, ${ }^{12}$ has remained uninterrupted until today especially in connection with religious texts. It is the oral recitation of the rșis who first transmitted the Vedas that provides the word with authority and informs the history of the relationship between orality and textuality in South Asia. The opening sentence evam me sutam in Pāli or evam maya śrutam in Sanskrit ('Thus have I heard') that frequently appears in the Buddhist Suttas and Āgamas is a statement about the oral nature of the Buddha's teaching and its initial transmission ${ }^{13}$-a statement that represents what Sheldon Pollock has called "the historical authentication of the text."14 Precisely the oral nature of a teaching and its verbatim repetition by an earwitness (for example the Buddha's disciple Ānanda) made the wording of that teaching reliable. Moreover, the authority of oral texts and the seal of "being heard" guaranteed the authoritativeness of texts in fields of knowledge as diverse as Dharma, grammar, or medicine. ${ }^{15}$ Also, the semantics of the Sanskrit word śruti, which indicates hearing as much as learning, provides an implicit reference to oral techniques more generally adopted in the transmission of knowledge. To reflect on how oral modalities related to texts are interwoven with written ones is neither new nor recent. However, it is not trivial to recall this because, based on a narrative concerning the cultural history of Europe and on further comparative arguments, orality has been opposed to literacy, and memory to documentary sources. ${ }^{16}$ Furthermore, it

de Gruyter, 2014), 159-81; and Sheldon Pollock, "Literary Culture and Manuscript Culture in Precolonial India," in Literary Cultures and the Material Book, eds. Simon Eliot et al., 77-94 (London: British Library, 2007).

11 Hartmut Scharfe, Education in Ancient India (Leiden, Boston: Brill, 2002), chapters 2, 12, 14 and 15 .

12 On this, see Charles Malamoud, "Noirceur de l'écriture. Remarques sur un thème littéraire de l'Inde ancienne," in Paroles à dire, paroles à écrire. Inde, Chine, Japon, ed. Viviane Alleton (Paris: Éditions de l'École des Hautes Études en Sciences Sociales, 1997), 85-114.

13 Étienne Lamotte, "The Assessment of Textual Authenticity in Buddhism," Buddhist Studies Review 1, no. 1 (1983-1984): 4-15.

14 Sheldon Pollock, "The Revelation of Tradition: śruti, smrti, and the Sanskrit Discourse of Power," in Boundaries, Dynamics and Constructions of Traditions in South Asia, ed. Federico Squarcini (Firenze: Firenze University Press, 2005), 50, n. 15.

15 Most useful in this respect is Ludo Rocher, "Orality and Textuality in the Indian Context," Sino-Platonic Papers 49 (1994): 1-28. See also the overview offered in Houben and Rath, "Introduction".

16 A paradigmatic case is Walter Ong, Orality and Literacy, first published in 1982 (London: Methuen \& Co.). 
has been claimed that rationality originated from literacy ${ }^{17}$ and, as recently as in 2000 , that the written word gives power to "cultures that possess writing over purely oral ones." ${ }^{18}$ South Asian cultural history clearly represents a strong counter-argument to such theses. ${ }^{19}$ Here, a two-thousand-years long history of manuscript production and a quite influential cult of the book in the Buddhist and Jain communities or, several centuries later, in the Sikh community show that oral culture and written culture can coexist and the one is neither physically, nor as regards authority and prestige eventually absorbed by the other. Even in China, where the written word was strongly associated with authority from very early on, ${ }^{20}$ the shift to the written-Anne Cheng has argued-was fundamentally considered a sign of decadence, and some exegetical schools claimed the authenticity of their tradition based on its oral transmission. ${ }^{21}$ In Tibet, too, where writing and books had and still have a special role in religious contexts, ${ }^{22}$ the written-Cristina Scherrer-Schaub has observed-did not "radically change the society" nor did it compete with orality. "Both were (and are) coexisting, albeit in an increasing variety of interwoven relations."23 The articles that follow illustrate some of the configurations in which print was integrated in traditional technologies for the record, transmission, and circulation of texts in South Asia.

\section{New Configurations}

Bhagavān Vedaḥ is the title of a printed publication that comprises all fourVedic Samphitās in one volume. Borayin Larios analyses the background and context

17 This was the thesis that Jack Goody elaborated in the 1960s and 1970s.

18 Jack Goody, The Power of the Written Tradition (Washington: Smithsonian Institute Press, 2000): 1. A criticism of this hypothesis and further detailed observations are provided by Houben and Rath, "Introduction," 23-35.

19 See Houben and Rath, "Introduction," 14-36, where relevant references are also provided.

20 See Mark Lewis, Writing and Authority in Early China (Albany, NY: State University of New York Press, 1999).

21 Anne Cheng, "Paroles des sages et écritures sacrées en Chine ancienne," in Paroles à dire, paroles à écrire. Inde, Chine, Japon, ed. Viviane Alleton (Paris: Éditions de l'École des Hautes Études en Sciences Sociales, 1997), 139-141.

22 Robert Ekvall observed that writing in Tibet "also furnishes the clearest example of an act that is an end in itself rather than a means to an end." This is shown, in particular, by rituals that include or are even based on the use of written materials whose communication function is simply not taken into account; see R. Ekvall, Religious Observances in Tibet: Patterns and Function (Chicago: Chicago University Press, 1964), 113-14.

23 Cristina Scherrer-Schaub, "Tibet: An Archaeology of the Written," in Old Tibetan Studies. Proceedings of the Tenth Seminar of the IATS, 2003, ed. Cristina Scherrer-Schaub (Leiden: Brill, 2012), 240. 
of this publication, which appeared in 1971 and was the result of a venture initiated by Guru Gangeśvarānand Mahārāj. The printing of Bhagavān Vedah appears as a unique enterprise if one appreciates that the Vedas were and still are traditionally transmitted through oral recitation, and that the earliest manuscripts bearing their text date back to the early second millennium CE. And it is also through recognizing the problematic relation of the Vedic tradition with the written that one can understand why reading, studying, or commercial purposes were irrelevant to Gangeśvaranand's project. Although Gangeśvaranand was eager to make the Vedic Saṃhitās available to everyone through translations and commentaries, the printing of what eventually became the 22 kilos Bhagavān Vedah book had in fact another goal, namely to materialize the four Vedic Saṃitās into a single physical book as a symbol for the tradition and its age-old authority. Therefore, special materials were used for producing the printed books, a new printing press was installed to ensure the purity of the printing process, and the printed books were ritually enthroned when taken to their final places. The selection of the recensions to be printed was the result of a long debate between pandits especially selected for accomplishing the task of providing a pure, correct version of the text. Eventually, a new entity was created by putting together text versions from different schools (śäkhas). Larios identifies the Hindu reform movements of the nineteenth century as well as Sikhism as major factors which led to viewing the Vedas as a book, or better to say the holy book of the Hindus, and eventually to its materializing in printed form. This also displays how Hinduism in some circles has come to be a 'religion of the book' and how those circles have built a complex relationship with their traditional oral and manuscript cultures.

Another quite complex configuration of oral tradition and writing is illustrated by Martin Gaenszle in his essay on an originally nonliterate ethnic group in Nepal, the Limbus. In the eighteenth century the Limbus created their own script as a means to preserve hitherto orally transmitted ritual and religious literature called Mundhum. The Limbu script is thus intertwined with the development of a new religious and literary tradition. But, as Gaenszle shows, there is more to this than canonization processes and the shaping of a particular linguistic style. In fact, while preserving their shamanistic religion, the Limbus' invention and use of a script mainly served the purpose of individuating their ethnic heritage as distinct from, and on the same level with the hegemonic Hindu parbatĩya culture of Nepal. Here, since the 199os many ethnic groups have tried to reframe or even reinvent their own past and culture by adopting structures similar to the rejected Hindu culture and filling them with contents belonging to the ethnic-specific cultural heritage. The creation of a religious literature is part of these efforts. So, the popularization of the Limbu 
script that comes with the production and dissemination of this literature is not just a project of religiously interested people, but rather belongs to the core of ethnic politics and self-representation. With the technical opportunities of the digital age, namely the creation of Limbu script in Unicode Fonts, the number of publications has exploded, and includes non-religious genres as well.

\section{Transborder Printing Ventures and Fluidity of Texts}

The essays by Alaka A. Chudal and Jessica V. Birkenholtz in this volume explore the publication history of two popular Nepali texts, the Vetālapañcavimiśati and the Svasthānīvratakathā respectively. While illustrating what happens to these texts through different modes of transmission and dissemination, both authors also deal with specific features of Nepali printing and provide important insights on this still poorly studied culture of printing. Especially in its initial period (the late nineteenth and early twentieth centuries), the printing of Nepali books was performed by migrant Nepalis in the neighbouring country India, more precisely in Benares, because the Rana regime restricted freedom of speech and press in Nepal, and competitive printing solutions were not available in the country. ${ }^{24}$ Despite such restrictions, the use of the printed book gradually increased and corresponded to an expansion of the readers community. The number of readers grew from the literate elites to a larger public whose readings were no longer confined to Sanskrit literature, but included books in vernacular Nepali. The close contact with the printing activity in Benaras entailed that the developments of Nepali printing were to some extent connected with the print culture in the Hindi belt of North India. With regard to the latter, Francesca Orsini has introduced the distinction between "genres reproduced" and "genres introduced", and argued that the Hindi and Urdu books published in the last decades of nineteenthcentury North India mainly consisted of "genres reproduced," ${ }^{25}$ namely genres existing in already established traditions and transmitted within oral or manuscript cultures. The early Nepali print history, too, was dominated by genres reproduced, as confirmed by the case studies presented by Chudal and Birkenholtz. Both authors deal with texts that are important representatives of

24 Alaka Atreya Chudal, "Nepali Intellectuals in Exile: The History of Nepali Printing in 19th-2oth Century Benares," Journal of South Asian Intellectual History 3 (2021), 1-26.

25 Francesca Orsini, "Detective Novels: A Commercial Genre in Nineteenth-century North India," in India's Literary History: Essays on the Nineteenth Century, eds. Stuart Blackburn et al. (Delhi: Permanent Black, 2004), 435-82. 
genres reproduced - in particular religious texts and tales—and have a long history of transmission preceding the adoption of print technology.

In exploring distinctions and continuities between different modes of textual reproduction, Chudal and Birkenholtz provide evidence for text fluidity across time and contexts. Chudal's essay, in particular, shows different dimensions of the Vetālapañcaviṇśati (a medieval Sanskrit anthology of riddle-tales) in connection with the oral, written, and printed Nepali versions of the work. Furthermore, it illustrates important variations based on activities concerning the text, in particular recitation, composition and printing, and based on agents linked to such activities, namely reciters, editors, copyists, and publishers. Trans-local oral attestations of the Nepali Vetālapañcavimśati indeed provide evidence for quite different receptions of the text and for the fluidity of its versions into the time of its appearance in print.

Birkenholtz's essay on the Svasthānivratakathā presents the complex history of the text from its first nucleus in Newari to the printed versions in Nepali. The author illustrates the contours of the Newari origin and identity of the Svasthānivratakathā as they emerge from the extant manuscript sources and evidence concerning its traditional recitation, and discusses how the text was physically expanded to a Nepali prose composition of thirty-one chapters that integrates Purānic elements and verses from the Sanskritic tradition. Textual fluidity and linguistic diversity are two key features of the Svasthānivratakathā that continue into its history in printing, showing how both features have been accommodated in the making of a print culture in the Nepalese region. The adoption of print, however, corresponded to changes in the uses of the text, changes that are not imputable to the circulation of the printed book, but to changes in the society at large in which the printed book circulated.

\section{Religious Hegemony through Printing}

As shown by the essays presented so far, the print publication of religious texts was quite dominant in various regions of South Asia. This dominant trend is the subject of Richard Weiss's essay, who starts from an analysis of the "Tamil library" of the German missionary Karl Graul and expands on publishing projects whose results are reflected in Graul's collection, in particular the books edited by Tamil scholar Vedagiri Mudaliyar and other members of his family in the first half of the nineteenth century. By using manuscripts, Vedagiri Mudaliyar and his family prepared the edition and attended to the publication of a range of religious books in Tamil, from Shaiva devotional pamphlets to publications against the caste system and against Shaiva temple-based 
practices. Weiss traces the roots of this non-sectarian choice in the challenge posed by Christian initiatives for evangelisation and missionary work. Since such initiatives importantly included the dissemination of printed pamphlets and books, Tamil scholars such as Vedagiri Mudaliyar arguably turned to printing in order to strengthen the Hindu tradition that expressed itself in Tamil. The Tamil library collected by the missionary Graul reflects a formative stage of Tamil print culture in which printing-dominated as it was by religious publishing - appeared as a tool for asserting and reconfiguring a Hindu hegemony, rather than paving the way for a specific sectarian tradition. Indeed, printed books in Graul's library contained forms of traditional knowledge preserved through a centuries-long manuscript culture, but also integrated new or newly formulated expositions of religious matters with Vaishnava, Siddha, or more conventional Shaiva texts. Graul's motivation for collecting Tamil printed books, namely learning the language and understanding the Volksgeist of Tamil people, displays a take on print as reflecting the picture of a static situation in society. On the contrary, however, the beginnings of Tamil print culture display a dynamic approach to print, with editors of religious books who, aiming to counter the Christian dominance of the printed book market, avoided adopting a sectarian approach.

\section{Conclusion}

The studies in this issue of Philological Encounters are an exercise in documenting and historicizing processes related to the production and dissemination of printed books in nineteenth- and twentieth-century South Asia. While focusing on the interdependence of print and other technologies for the reproduction of texts, they illustrate events in the formative stage of print cultures as diverse as those related to Vedic, Limbu, Nepali, Newari, and Tamil cultures; they add to a narrative of the functions of printed books and the roles of local agencies in these cultures. Furthermore, besides hinting at the vastness of the matter to be explored, these studies provide a synergetic perspective that goes beyond disciplinary boundaries and the fragmentation of expertise.

\section{Acknowledgements}

For academic purposes, Johanna Buss is responsible for the section "New configurations", Alaka A. Chudal for the section "Transborder printing ventures and fluidity of texts", and Cristina Pecchia for the other sections. The authors wish to thank the sponsors of the symposium "Manuscript, Print 
and Publication Cultures in South Asia": the Institute for the Cultural and Intellectual History of Asia (Austrian Academy of Sciences); the Department of South Asian, Tibetan and Buddhist Studies, the Dean's Office of the Faculty of Philological and Cultural Studies, the Center for Interdisciplinary Research and Documentation of Inner and South Asian Cultural History, the De Nobili Research Library (University of Vienna); and the Österreichische Forschungsgemeinschaft.

\section{Bibliography}

Almogi, Orna, ed. Tibetan Manuscript and Xylograph Traditions. The Written Work and Its Media within the Tibetan Cultural Sphere. Hamburg: Department of Indian and Tibetan Studies, University of Hamburg, 2016.

Brokaw, Cynthia J., and Kai-Wing Chow, eds. Printing and Book Culture in Late Imperial China. Berkeley: University of California Press, 2005.

Bühler, Curt Ferdinand. The Fifteenth Century Book. The Scribes, the Printers, the Decorators. Philadelphia: University of Pennsylvania Press, 1960.

Chance, Linda H., and Julie Nelson Davis. "The Handwritten and the Printed. Issues of Format and Medium in Japanese Premodern Books." Journal for Manuscript Studies 1 (2017): 90-114.

Cheng, Anne. "Paroles des sages et écritures sacrées en Chine ancienne." In Paroles à dire, paroles à écrire. Inde, Chine, Japon, edited by Viviane Alleton, 139-55. Paris: Éditions de l'École des Hautes Études en Sciences Sociales, 1997.

Chudal, Alaka A. "Nepali Intellectuals in Exile: The History of Nepali Printing in 19th-2oth Century Benares." Journal of South Asian Intellectual History 3 (2021): $1-26$.

Diemberger, Hildegard, Karl Ehrhard, Peter F. Kornicki, eds. Tibetan Printing: Comparisons, Continuities, and Change. Brill: Leiden, 2016.

Ekvall, Robert. Religious Observances in Tibet: Patterns and Function. Chicago: Chicago University Press, 1964.

Formigatti, Camillo. "A Forgotten Chapter in South Asian Book History? A Bird's Eye View of Sanskrit Print Culture." In Tibetan Printing: Comparison, Continuities, and Change, edited by Hildegard Diemberger, Karl Ehrhard, and Peter F. Kornicki, 72-134. Leiden: Brill, 2016.

Formigatti, Camillo. "Manuscript Studies: Crisis on Infinite Methods." In The Study of Asia between Antiquity and Modernity: Proceedings of the First Coffee Break Conference, edited by Elisa Freschi et al., 43-9. Special issue of Rivista degli Studi Orientali 84 (2011). 
Galewicz, Cezary. Kingdoms of Memory, Empires of Ink: The Veda and the Regional Print Cultures of Colonial India. Krakow: Jagiellonian University Press, 2020.

Ghosh, Anindita. Power in print. New Delhi: Oxford University Press, 2006.

Ghosh, Anindita. "An Uncertain 'Coming of the Book': Early Print Cultures in Colonial India." Book History 6 (2003): 23-55.

Goody, Jack. The Power of the Written Tradition. Washington, London: Smithsonian Institute Press, 2000.

Gupta, Abhijit, and Swapan Chakravorty, eds. Founts of Knowledge. Delhi: Permanent Black, 2015.

Gupta, Abhijit, and Swapan Chakravorty, eds. Moveable Type: Book History in India. Ranikhet: Permanent Black, 2008.

Gupta, Abhijit, and Swapan Chakravorty, eds. Print Areas. Book History in India. Delhi, Bangalore: Permanent Black, 2004.

Houben, Jan E. M., and Saraju Rath. "Introduction: Manuscript Culture and Its Impact in 'India': Contours and Parameters." In Aspects of Manuscript Culture in South India, edited by S. Rath, 1-53. Leiden: Brill, 2012.

Kesavan, B. S. History of Printing and Publishing in India. A Story of Cultural Re-awakening. New Delhi: National Book Trust, 1985.

Lamotte, Étienne. "The Assessment of Textual Authenticity in Buddhism." Buddhist Studies Review 1, no. 1 (1983-1984): 4-15 (English translation by Sara Boin-Webb of: "La critique d'authenticité dans le Bouddhisme." In India Antiqua. A Volume of Oriental Studies Presented to J. P. Vogel, 216-232. Leiden: Kern Institute, 1947).

Lewis, Mark. Writing and Authority in Early China. Albany, New York: State University of New York Press, 1999.

Lin, Hang, and 林航. “Intersecting Boundaries: Manuscript, Printing, and Book Culture in Late Ming China." Oriens Extremus $5^{2}$ (2013): 263-304.

Malamoud, Charles. "Noirceur de l'écriture. Remarques sur un thème littéraire de l'Inde ancienne." In Paroles à dire, paroles à écrire. Inde, Chine, Japon, edited by Viviane Alleton, 85-114. Paris: Éditions de l'École des Hautes Études en Sciences Sociales, 1997 .

McKenzie, D. F. Bibliography and the Sociology of Texts. Cambridge: Cambridge University Press, 1999.

McKitterick, David. Print, Manuscript and the Search for Order, 1450-1830. Cambridge: Cambridge University Press, 2003.

Mullaney, Thomas S., ed. Facing the World: Towards a Global History of Non-Latin Type Design. Special issue of Philological Encounters 3 (2018).

Ong, Walter. Orality and Literacy. London: Methuen \& Co., 1982.

Orsini, Francesca, ed. The History of the Book in South Asia. Farnham: Ashgate, 2013. 
Orsini, Francesca. "Detective Novels: A Commercial Genre in Nineteenth-century North India." In India's Literary History: Essays on the Nineteenth Century, edited by Stuart Blackburn and Vasudha Dalmia, 435-82. Delhi: Permanent Black, 2004.

Pollock, Sheldon. "Literary Culture and Manuscript Culture in Precolonial India." In Literary Cultures and the Material Book, edited by Simon Eliot, Andrew Nash, and Ian Willison, 77-94. London: British Library, 2007.

Pollock, Sheldon. "The Revelation of Tradition: śruti, smrti, and the Sanskrit Discourse of Power." In Boundaries, Dynamics and Constructions of Traditions in South Asia, edited by Federico Squarcini, 41-61. Firenze: Firenze University Press, 2005.

Priolkar, Anant Kabka. The Printing Press in India. Bombay: Marathi Samshodhana Mandala, 1958.

Rocher, Ludo. "Orality and Textuality in the Indian Context." Sino-Platonic Papers 49 (1994): 1-28.

Schaeffer, Kurtis. The Culture of the Book in Tibet. New York Chichester, West Sussex: Columbia University Press, 2009.

Scharfe, Hartmut. Education in Ancient India. Leiden, Boston: Brill, 2002.

Scherrer-Schaub, Cristina. "Tibet: An Archaeology of the Written." In Old Tibetan Studies. Proceedings of the Tenth Seminar of the IATS, 2003, edited by Cristina Scherrer-Schaub, 217-247. Leiden: Brill, 2012.

Shaw, Graham W. Printing in Calcutta to 1800. A Description and Checklist of Printing in Late 18th-Century Calcutta. London: The Bibliographical Society, 1981.

Stallybrass, Peter. "Printing and the Manuscript Revolution." In Explorations in Communication and History, edited by Barbie Zelizer, 111-18. New York: Routledge, 2008.

Stark, Ulrike. An Empire of Books: Naval Kishore Press and the Diffusion of the Printed Word in Colonial India. New Delhi: Permanent Black, 2008.

Stark, Ulrike. Chapakhana. https://chapakhana.rcc.uchicago.edu. 2018-2021, accessed April 14, 2021.

Venkatachalapathy, A. R. The Province of the Book: Scholars, Scribes and Scribblers in Colonial Tamilnadu. Ranikhet: Permanent Black, 2012.

Wujastyk, Dominik. "Indian Manuscripts." In Manuscript Cultures. Mapping the Field, edited by Jörg Quenzer, Dmitry Bondarev, Jan-Ulrich Sobisch, 159-81. Berlin, Munich, Boston: Walter de Gruyter, 2014. 